\title{
Postganglionic muscarinic inhibitory receptors in pulmonary parasympathetic nerves in the guinea-pig
}

\author{
D. Faulkner, Allison D. Fryer \& Jennifer Maclagan ${ }^{1}$
}

Pharmacology Department, Royal Free Hospital School of Medicine, Rowland Hill Street, London NW3 2PF

1 The location of neuronal inhibitory muscarinic receptors in pulmonary parasympathetic nerves was investigated in vivo and in vitro. The effects of an agonist for neuronal muscarinic receptors (pilocarpine) and an antagonist (gallamine) were tested on contractions of airway smooth muscle induced by pre- and postganglionic cholinergic nerve stimulation.

2 In anaesthetized guinea-pigs, gallamine potentiated constriction of the tracheal tube and smaller airways induced by preganglionic stimulation. Gallamine also potentiated postganglionic stimulation induced by transmural stimulation of the tracheal tube and by 1-1-dimethyl-4-phenylpiperazinium iodide in the rest of the lung.

3 Bronchoconstriction and contraction of the tracheal tube induced by intravenous acetylcholine were not potentiated by gallamine, indicating that postjunctional muscarinic receptors in airway smooth muscle were not involved in the potentiation.

4 The muscarinic agonist, pilocarpine, had the opposite effect to gallamine and inhibited contractions of the tracheal tube induced by both types of nerve stimulation.

5 In vitro, the inhibitory effect of pilocarpine was demonstrated in the tracheal tube preparation stimulated both pre- and postganglionically. The effect of pilocarpine was antagonized by gallamine. 6 Because gallamine and pilocarpine affected the responses to postganglionic stimulation, the inhibitory muscarinic receptors must be located on the postganglionic neurones of the parasympathetic nerves innervating the trachea and the smaller airways. However, these experiments cannot exclude the possibility that muscarinic receptors may also be located on the soma of the ganglion cells.

\section{Introduction}

Neuronal muscarinic receptors have an inhibitory function on parasympathetic nerve transmission to airway smooth muscle in both cats and guinea-pigs (Fryer \& Maclagan, 1984; Blaber et al., 1985). Gallamine is an antagonist and pilocarpine an agonist for these receptors and these drugs enhance and inhibit vagally-induced bronchoconstriction respectively.

The autonomic nerves supplying the bladder (Gallagher et al., 1982), intestine (Fosbraey \& Johnson, 1980), heart (Fuchs \& Fuder, 1985) and blood vessels (Shepherd et al., 1978) are known to contain neuronal muscarinic receptors. In these tissues, the receptors are located in the ganglia (Suzuki \& Volle, 1979; Gallagher et al., 1982; Morita et al., 1982; Ashe \& Yarosh, 1984) and on the postganglionic final nerve terminals (Loffelholz \& Muscholl, 1970; Kilbinger \& Wagner, 1979; Fox et al., 1985; Wetzel \& Brown,

\footnotetext{
'Author for correspondence.
}

1985). In the previous studies by Fryer \& Maclagan the preganglionic vagal nerve trunk was stimulated and the results could not demonstrate whether the pulmonary muscarinic inhibitory receptors were located on the soma of the ganglion cell or on the final terminals of the postganglionic neurone. The experiments described in this paper were carried out to determine the location of these muscarinic receptors by testing the effects of gallamine and pilocarpine on tracheal tube contractions induced by pre- and postganglionic nerve stimulation in vivo and in vitro.

\section{Methods}

In vivo experiments

Guinea-pigs (350-450 g) of the Dunkin Hartley strain (Graystone of Hampshire) were anaesthetized with 
urethane (Sigma Ltd. $1.50 \mathrm{~g} \mathrm{~kg}^{-1}$ i.p.). The right carotid artery was cannulated for the measurement of heart rate and blood pressure and the right jugular vein was cannulated for the administration of drugs.

The trachea was exposed from the larynx to the sternum and divided into an upper 'cervical' section, and a lower 'thoracic' section. The thoracic trachea was cannulated for ventilation of the animal. Great care was taken to preserve both the blood and nerve supply (the recurrent laryngeal nerve) to the cervical trachea which was tied at both ends to form an in situ tube filled with $0.9 \%$ saline. The tracheal tube was cannulated at the proximal end and internal pressure was measured with a Statham (P23Db) transducer. An electrode was placed inside the tube and another was placed outside in a pool of saline so that the tube could be stimulated transmurally. Both vagi were cut and the distal ends placed on shielded platinum electrodes for preganglionic stimulation.

The animals were paralysed with either suxamethonium $\left(100 \mu \mathrm{g} \mathrm{kg}^{-1}\right.$, injected at $10 \mathrm{~min}$ intervals) or with (+)-tubocurarine $\left(1.5 \mathrm{mg} \mathrm{kg}^{-1}\right)$. As there was no difference between the results obtained with these two neuromuscular blocking drugs, the experimental results were combined.

The animals were artificially respired with a positive pressure, constant volume Harvard Rodent respiration pump and airflow, tidal volume and pulmonary inflation pressure $\left(\mathrm{P}_{\mathrm{pi}}\right)$ were recorded as described previously (Fryer \& Maclagan, 1984). Bronchoconstriction was measured as an increase in $P_{p i}$. Arterial blood samples were taken at the start and finish of each experiment and analysed for $\mathrm{pH}$ and $\mathrm{O}_{2}$ and $\mathrm{CO}_{2}$ tension, with a Corning 166 microsampler blood gas analyser. At the start of the experiment, ventilation was adjusted to give blood gas values in the normal range (Green, 1982). The animal's body temperature was maintained at $37^{\circ} \mathrm{C}$ with a CFP 8185 homeothermic blanket control.

Thirty minutes before the start of the experiment, the animals were treated with guanethidine $\left(4 \mathrm{mg} \mathrm{kg}^{-1}\right.$ i.v.) to deplete neuronal catecholamines and prevent any effects of sympathetic nerve stimulation. At the end of these experiments, depletion of noradrenaline was confirmed by the absence of a pressor response to tyramine $\left(10 \mathrm{mg} \mathrm{kg}^{-1}\right.$ i.v. $)$.

\section{In vitro experiments}

Guinea-pigs $(250-300 \mathrm{~g})$ were anaesthetized as described above and the trachea removed with the right recurrent laryngeal and vagus nerve attached as described by Blackman \& McCaig (1983). The trachea was tied into a tube, filled with Krebs-Hensleit solution, cannulated and suspended in a bath of the solution (composition $\mathrm{mM}$ : $\mathrm{NaCl} 118.4, \mathrm{KCl} 4.7$, $\mathrm{NaHCO}_{3}$ 25.0, glucose 11.1, $\quad \mathrm{KH}_{2} \mathrm{PO}_{4} 1.16$,
$\mathrm{MgSO}_{4} .7 \mathrm{H}_{2} \mathrm{O} 1.19$ and $\mathrm{CaCl}_{2} 2.6$ ) bubbled with $95 \%$ $\mathrm{O}_{2}$ and $5 \% \mathrm{CO}_{2}$ and maintained at $37^{\circ} \mathrm{C}$.

An electrode was placed inside the tube and another outside for transmural stimulation, and the vagus nerve was drawn through silver-chloride ring electrodes for preganglionic stimulation. The stimulation parameters used were $30 \mathrm{~Hz}, 0.2 \mathrm{~ms}, 30 \mathrm{~V}$ for $5 \mathrm{~s}$ at $40 \mathrm{~s}$ intervals. Contractions of the trachealis muscle were measured as increases in tube pressure recorded with a Statham (P23AC) transducer. At the end of each experiment the stimulus location was confirmed by abolition of the response to preganglionic stimulation by hexamethonium $(25 \mu \mathrm{M})$ and the response to transmural stimulation by atropine $(15 \mu \mathrm{M})$ in the presence of hexamethonium.

When indomethacin $(10 \mu \mathrm{M})$ was added to the reservoir of Krebs solution, the contractions of the muscle to pre- or postganglionic stimulation remained consistent for at least $4 \mathrm{~h}$ (Walters et al., 1984). However, the size of the contraction varied between tissues, so the results for each tissue have been expressed as the ratio $\left(B_{2} / B_{1}\right)$ of the response after the agonist $\left(B_{2}\right)$ to the response before $\left(B_{1}\right)$. All other drugs were added directly to the organ bath.

\section{Drugs}

The drugs used in these experiments were: gallamine triethiodide (May and Baker), hexamethonium bromide (Koch-Light), indomethacin (Sigma), 1-1dimethyl-4-phenylpiperazinium iodide (DMPP) (Aldrich), atropine sulphate, acetylcholine bromide, pilocarpine nitrate (BDH) and U64419 (stable thromboxane analogue) (Upjohn). All drugs were dissolved and diluted in $0.9 \%$ saline, except for U64419 which was dissolved in ethanol and diluted in $0.9 \%$ saline, and indomethacin which was made up in a buffer $\left(\mathrm{KH}_{2} \mathrm{PO}_{4} 19.76 \mathrm{mM}\right.$ and $\left.\mathrm{Na}_{2} \mathrm{HPO}_{4} 118.34 \mathrm{mM}\right)$ and the $\mathrm{pH}$ adjusted to 7.8 with $\mathrm{NaOH}$.

\section{Results}

\section{Experiments in vivo}

In 5 guinea-pigs anaesthetized with urethane and pretreated with guanethidine, stimulation of the cervical vagus nerves $(15 \mathrm{~Hz}, 0.2 \mathrm{~ms}, 20 \mathrm{~V}, 3 \mathrm{~s}$ duration) produced bradycardia (mean decrease in heart rate $135 \pm 25$ beats $\min ^{-1}$ ); bronchoconstriction (mean increase in pulmonary inflation pressure, $\mathrm{P}_{\mathrm{pi}}$ of $37.4 \pm 13.9 \mathrm{mmH}_{2} \mathrm{O}$ ) and contraction of the cervical tracheal tube (mean increase in pressure of $7.1 \pm 2.4 \mathrm{mmH}_{2} \mathrm{O}$ ). The responses obtained in one experiment are shown in the first panel of Figure 1 (open arrow, Pre). All of the responses produced by stimulation of the cervical vagus nerve were abolished 


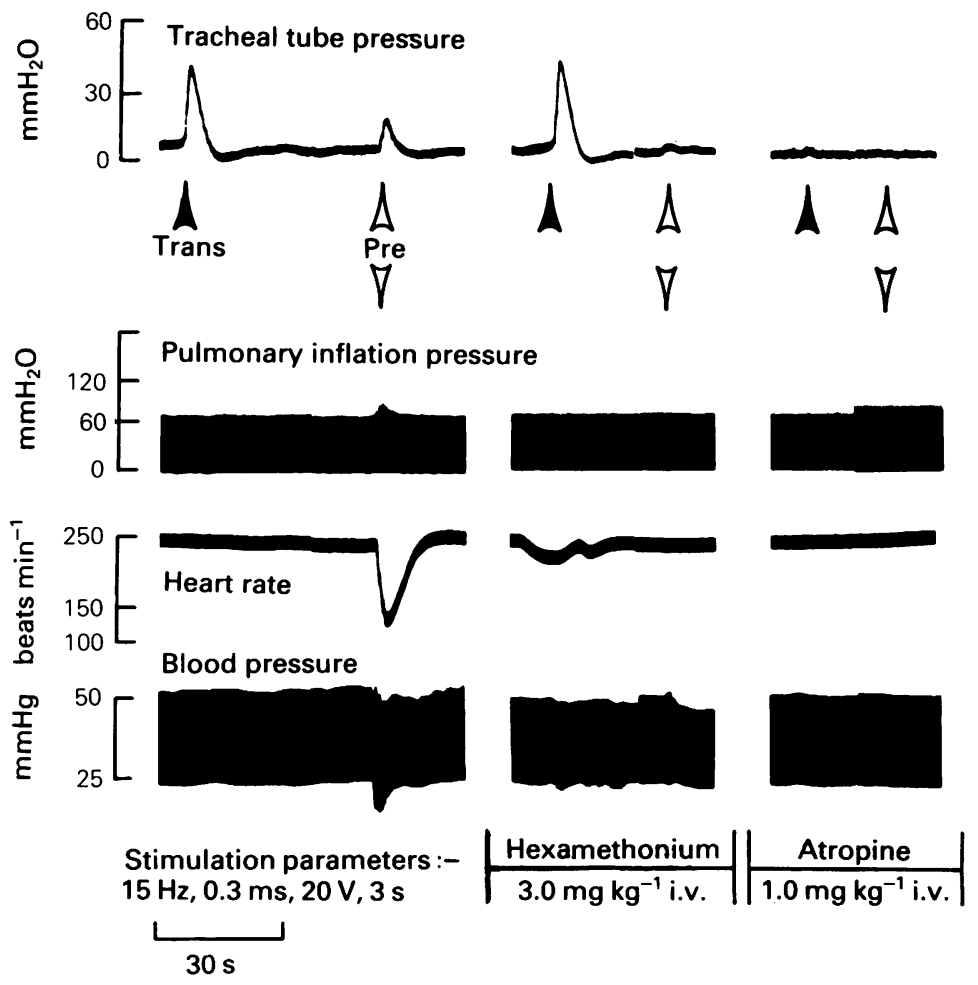

Figure 1 The increases in tracheal tube pressure, pulmonary inflation pressure and the fall in heart rate induced by preganglionic stimulation of the vagus nerve (Pre, open arrows) were blocked by hexamethonium. Transmural stimulation of the tracheal tube (Trans, solid arrows) produced an increase in tube pressure which was unaffected by hexamethonium but abolished by atropine, indicating stimulation of postganglionic, cholinergic nerves.

by hexamethonium $\left(3.0 \mathrm{mg} \mathrm{kg}^{-1}\right.$ i.v.; centre panel of Figure 1) indicating that they were due to stimulation of preganglionic nerve fibres.

Transmural stimulation of the tracheal tube in the same animals (Figure 1, solid arrow, Trans) produced a mean rise in tube pressure of $30.0 \pm 7.8 \mathrm{mmH}_{2} \mathrm{O}$. This response was not affected by hexamethonium but was abolished by atropine (see right-hand panel of Figure 1) indicating that the increase in pressure was due to stimulation of postganglionic, cholinergic nerves. There was no apparent stimulus spread from the transmural electrodes as neither $\mathbf{P}_{\mathrm{pi}}$ nor heart rate were affected by transmural stimulation.

The control responses of the tracheal tube to preganglionic stimulation were smaller than those elicited by transmural stimulation. This occurred because the parameters for preganglionic stimulation had to be limited in order to avoid causing cardiac arrest and lung collapse.
Contractions of the tracheal tube in situ indured by both pre- and postganglionic stimulation were potentiated by gallamine (shown as an increase in $\mathbf{B}_{2} / \mathbf{B}_{1}$ ratio; Figure 2a). Gallamine was administered in cumulative doses and the responses increased in a dose-dependent manner. Although gallamine appears to have a greater effect on the responses to preganglionic stimulation than on those elicited by postganglionic stimulation, the difference between the results was not statistically significant.

Gallamine also potentiated the bronchoconstriction (increase in $\mathrm{P}_{\mathrm{pi}}$ ) produced by preganglionic vagal nerve stimulation in the smaller airways. This is shown in Figure $2 b$.

In order to stimulate the postganglionic nerves innervating the smaller airways, the ganglionic nicotinic receptors were stimulated with DMPP (Leff et al., 1983) in a separate set of experiments. Guanethidine was given to block the effects of sympathetic 


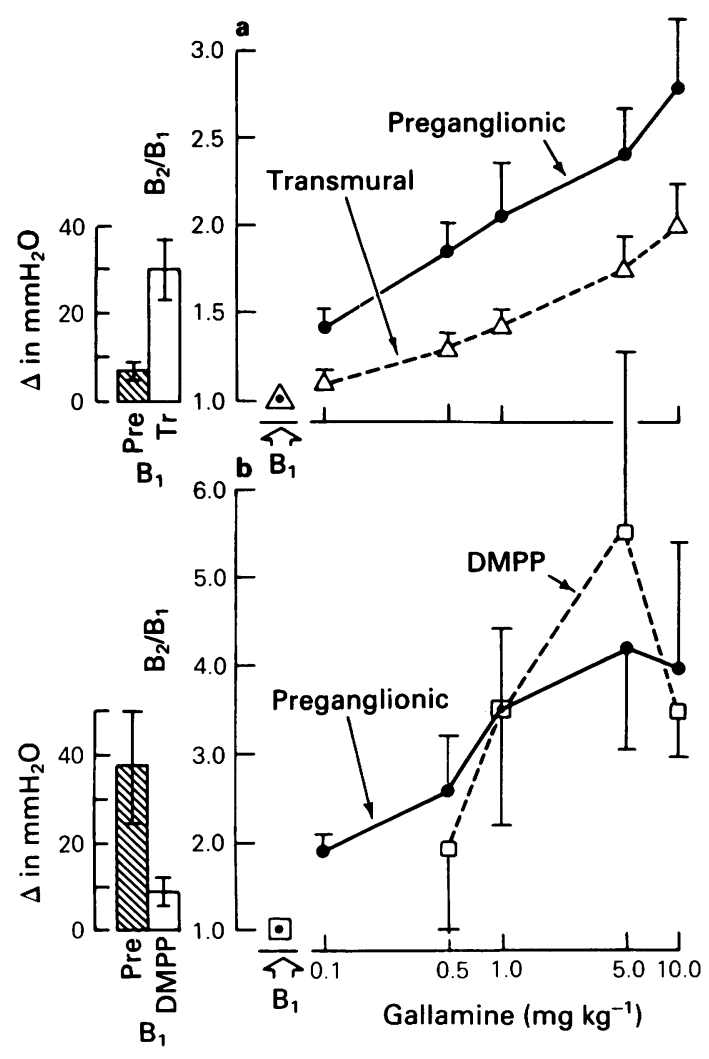

Figure 2 Contraction of airway smooth muscle was recorded from the tracheal tube in situ as an increase in pressure (a) and from the smaller airways as in increase in pulmonary inflation pressure (b). Control responses $\left(B_{1}\right.$, $\mathrm{mmH}_{2} \mathrm{O}$ ) elicited by preganglionic (hatched columns) and postganglionic (open columns) stimulation $(15 \mathrm{~Hz}$, $0.3 \mathrm{~ms}, 20 \mathrm{~V}$ for $3 \mathrm{~s}$ ) are shown on the left; these have been plotted on the graphs as 1.0. In the smaller airways, postganglionic stimulation was elicited by DMPP ( $\square$, $25 \mu \mathrm{g} \mathrm{kg}^{-1}$ i.v.).

Gallamine potentiated the bronchoconstriction induced by both pre $(O)$ and postganglionic $(\Delta$ and $\square)$ stimulation as shown by increases in the ratio $B_{2} / B_{1}$ where $\mathbf{B}_{2}$ is the response after gallamine (results are expressed as the mean with vertical lines showing s.e.mean; $n=5$ ).

ganglion stimulation and under these conditions, DMPP $\left(25 \mu \mathrm{g} \mathrm{kg}^{-1}\right.$ i.v., given at $15 \mathrm{~min}$ intervals) produced a mean increase in $\mathrm{P}_{\mathrm{pi}}$ of $8.3 \pm 3.9 \mathrm{mmH}_{2} \mathrm{O}$. This response was abolished by atropine $\left(1 \mathrm{mg} \mathrm{kg}^{-1}\right.$, i.v.) indicating that it was due to stimulation of parasympathetic ganglia. The DMPP-induced bronchoconstriction in the smaller airways was potentiated by gallamine in a dose-dependent manner. Figure $2 b$ shows that the effect of gallamine on DMPP-induced bronchoconstriction was comparable to its effect on

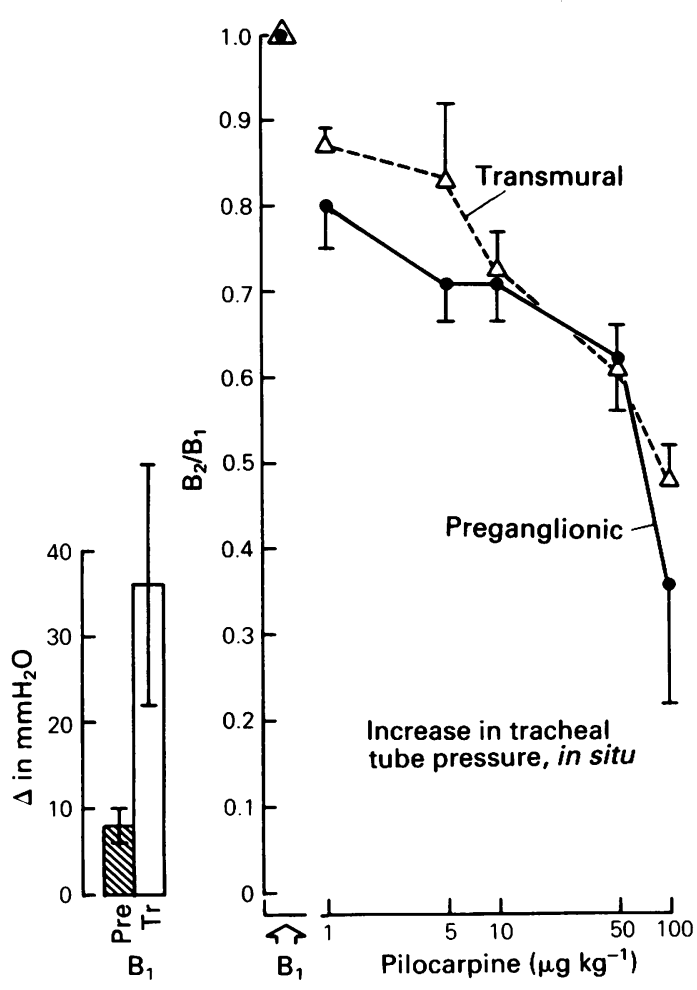

Figure 3 Tracheal tube in situ: cumulative doses of pilocarpine inhibited contraction of the tube induced by both preganglionic $(O)$ and by transmural $(\Delta)$ stimulation ( $15 \mathrm{~Hz}, 0.3 \mathrm{~ms}, 20 \mathrm{~V}$ for $3 \mathrm{~s}$ ) as shown by a decrease in the ratio $\mathrm{B}_{2} / \mathrm{B}_{1}$. Control responses $\left(\mathrm{B}_{1}, \mathrm{mmH}_{2} \mathrm{O}\right)$ elicited by preganglionic (hatched column) and postganglionic (open column) are shown on the left; these have been plotted as 1.0 on the graph. Mean results $(n=5)$ plotted with nomenclature used in Figure 2.

bronchoconstriction induced by preganglionic nerve stimulation.

Bronchoconstriction and constriction of the tracheal tube induced by i.v. acetylcholine ( $\mathrm{ACh}$ ) were not potentiated by gallamine, indicating that muscarinic receptors in airway smooth muscle were not involved in the potentiation.

The muscarinic agonist, pilocarpine, had the opposite effect to that of gallamine. Pilocarpine has been shown to inhibit bronchoconstriction induced by preganglionic nerve stimulation in the whole lung (Fryer \& Maclagan, 1984) and this effect has now been demonstrated in the tracheal tube (Figure 3). In addition, Figure 3 shows that pilocarpine also inhibited contractions elicited by transmural stimulation in a dose-dependent manner. 


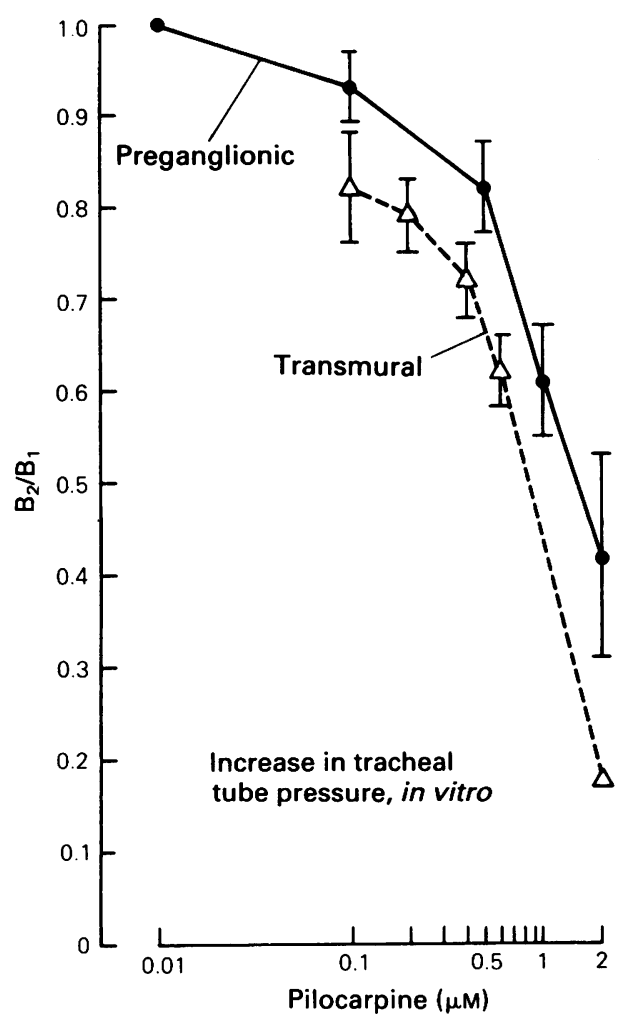

Figure 4 Transmurally stimulated tracheal tube in vitro: cumulative doses of pilocarpine inhibited contractions of the tracheal tube elicited by preganglionic $(O)$ and by transmural $(\Delta)$ stimulation $(30 \mathrm{~Hz}, 0.2 \mathrm{~ms}, 5 \mathrm{~s}, 150$ pulses) as shown by a decrease in the ratio $B_{2} / B_{1}$. Mean results $(n=5)$ are plotted with nomenclature used in Figure 2.

\section{Experiments in vitro}

In the isolated tracheal tube, preganglionic stimulation of the vagal nerve trunk or transmural stimulation of the intramural postganglionic neurones, caused transient, reproducible increases in tracheal tube pressure. Pilocarpine produced a dose-related inhibition of both preganglionic and transmurally-induced contractions of the tube (see Figure 4 and 5) and gallamine antagonized the effects of pilocarpine whether given before or during the action of the agonist.

In vitro, pilocarpine also had an additional postsynaptic effect, which produced a slow rise in pressure as shown in Figure 5a. However, the reduction in nerveinduced contraction height produced by pilocarpine was not related to the rise in tone, because a comparable increase in internal pressure produced by the stable thromboxane analogue, U64419, in the same experiment did not affect the contractions induced by transmural stimulation (see Figure 5b). U64419 was given at the end of every experiment in order to confirm that inhibition of nerve-induced contractions was not related to tone changes.

\section{Discussion}

The existence of neuronal muscarinic inhibitory receptors in the lung has previously been demonstrated in parasympathetic nerves supplying airway smooth muscle in guinea-pigs (Fryer \& Maclagan, 1984) and in cats (Blaber et al., 1985). Gallamine is an antagonist and pilocarpine an agonist for these receptors, so that these drugs produce potentiation or inhibition of vagally-induced bronchoconstriction respectively. The experiments described in this paper demonstrate that these inhibitory muscarinic receptors must have a postganglionic location on the parasympathetic nerves innervating both the trachea and the smaller airways below the trachea.

It has been demonstrated that under the chosen experimental conditions, contractions of the tracheal tube induced by transmural stimulation were due to excitation of postganglionic cholinergic nerves, as the responses were not altered by hexamethonium but were abolished by atropine. The transmurally-elicited contractions were potentiated by gallamine and inhibited by pilocarpine, indicating that the muscarinic inhibitory receptors must have a postganglionic location in cholinergic nerves innervating the trachea. Similarly, a postganglionic location for the muscarinic receptors in the innervation to the rest of the airways is indicated, as DMPP-induced bronchoconstriction was also potentiated by gallamine.

Neuronal muscarinic receptors have been reported to attenuate transmission in sympathetic nerves (Loffelholz \& Muscholl, 1970; Cole \& Shinnick-Gallagher, 1984) but any influence of the sympathetic nervous system was removed in these experiments by pretreatment with guanethidine.

In the parasympathetic nervous system, muscarinic inhibitory receptors have been identified in ganglia (Suzuki \& Volle, 1979; Gallagher et al., 1982). Muscarinic receptors have also been reported in postganglionic locations in the parasympathetic nerves innervating the guinea-pig ileum (Kilbinger \& Wagner, 1979; Fosbraey \& Johnson, 1980), the canine intestine (Fox et al., 1985) and the rat heart (Wetzel \& Brown, 1985). The results presented here indicate that muscarinic inhibitory receptors are located postganglionically in the parasympathetic nerves innervating the guinea-pig trachea and lung.

In parasympathetic nerves innervating the guineapig ileum, muscarinic inhibitory receptors have been 


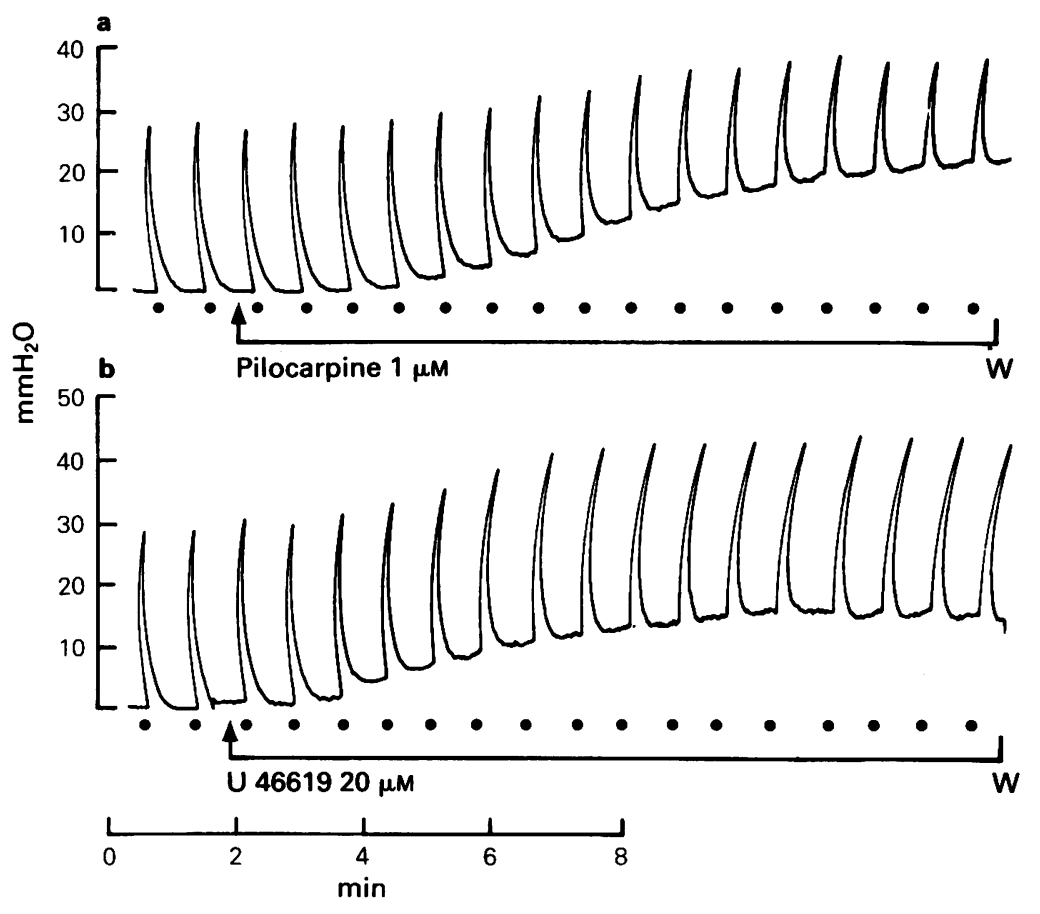

Figure 5 (a) Transmurally stimulated tracheal tube in vitro. Pilocarpine (1 $\mu \mathrm{M})$ inhibited contractions of the tube induced by transmural stimulation (at dots) and also produced a slow rise in tube pressure. Stimulation parameters: $30 \mathrm{~Hz}, 0.2 \mathrm{~ms}, 5 \mathrm{~s}$ and 150 pulses. However, the reduction in nerve-induced contraction is not related to the slow increase in tone because a comparable increase in tone induced by U64419 (b) did not affect the contractions induced by transmural stimulation in the same preparation.

found in the myenteric plexus (Kilbinger \& Wagner, 1979; Morita et al., 1982) in addition to those on the postganglionic neurones (Dzieniszewski \& Kilbinger, 1978; Fosbraey \& Johnson, 1980). The lung and the gut are derived from the same embryological tissue and many similarities in their innervation have been found, so it is possible that inhibitory muscarinic

\section{References}

ASHE, J.H. \& YAROSH, C.A. (1984). Differential and selective antagonism of the slow-inhibitory postsynaptic potential and slow-excitatory postsynaptic potential by gallamine and pirenzepine in the superior cervical ganglion of the rabbit. Neuropharmacology, 23, 1321-1329.

BLABER, L.C., FRYER, A.D., MACLAGAN, J. (1985). Neuronal muscarinic receptors attenuate vagally-induced contraction of feline bronchial smooth muscle. $\mathrm{Br}$. J. Pharmac., 86, 723-728.

BLACKMAN, J.G. \& McCAIG, D.J. (1983). Studies on an isolated innervated preparation of guinea-pig trachea. $\mathrm{Br}$. J. Pharmac., 80, 703-710.

COLE, A. \& SHINNICK-GALlAGHER, P. (1984). Muscarinic receptors may have multiple locations in the lung as they do in the ileal innervation. The experiments reported here can not exclude the possibility that neuronal muscarinic receptors may be located in the pulmonary parasympathetic ganglia, in addition to those described in this paper on postganglionic neurones. inhibitory transmission in mammalian sympathetic ganglia mediated by increased potassium conductance. Nature, 307, 270-271.

DZIENISZEWSKI, P. \& KILBINGER, H. (1978). Muscarinic modulation of acetylcholine release evoked by methylphenylpiperazinium and high potassium from guinea-pig myenteric plexus. Eur. J. Pharmac., 50, 385-391.

FOSBRAEY, P. \& JOHNSON, E.S. (1980). Release-modulating acetylcholine receptors on cholinergic neurones of the guinea-pig ileum. Br. J. Pharmac., 68, 289-300.

FOX, J.E., DANIEL, E.E., JURY, J., ROBOTHAM, H. (1985). Muscarinic inhibion of canine small intestinal motility in vivo. Am. J. Physiol., 248, G526-G531. 
FRYER, A.D. \& MACLAGAN, J. (1984). Muscarinic inhibitory receptors in pulmonary parasympathetic nerves in the guinea-pig. Br. J. Pharmac., 83, 973-978.

FUCHS, P. \& FUDER, H. (1985). The determination of presynaptic $\mathrm{K}_{\mathrm{A}}$ values of methacholine and pilocarpine and of a presynaptic receptor reserve in the rat heart. $\mathrm{Br}$. J. Pharmac., 84, 35-46.

GALLAGHER, J.P., GRIFFITH, W.H., SHINNICKGALLAGHER, P. (1982). Cholinergic transmission in cat parasympathetic ganglia. J. Physiol., 332, 473-486.

GREEN, C.J. (1982). Animal Anaesthesia: Laboratory Animal Handbooks, Vol. 8. p. 142. London: Laboratory Animals Ltd.

KILBINGER, H. \& WAGNER, B. (1979). The role of presynaptic muscarinic receptors in regulating acetylcholine release from peripheral cholinergic neurones. In Advances in the Biosciences. ed. Langer, S.Z., Starke, K. \& Dubocovich, M.L. Vol. 18, pp. 347-351. Oxford: Pergamon.

LEFF, A.R., MUNOZ, N.M. \& HENDRIX, S.G. (1983). Parasympathetic and adrenergic contractile responses in canine trachea and bronchus. J. appl. Physiol., 55, 113-120.
LOFFELHOLZ, K. \& MUSCHOLL, E. (1970). Inhibition by parasympathetic nerve stimulation of the release of the adrenergic transmitter. Naunyn-Schmiedebergs Arch. Pharmac., 267, 181-184.

MORITA, K., NORTH, R.A. \& TOKIMASA, T. (1982). Muscarinic presynaptic inhibition of synaptic transmission in myenteric plexus of guinea-pig. J. Physiol., 333, 141-149.

SHEPHERD, J.T., LORENZ, R.R., TYCE, G.M. \& VANHOUTTE, P.M. (1978). Acetylcholine-inhibition of transmitter release from adrenergic nerve terminals mediated by muscarinic receptors. Fedn Proc., 37, 191-194.

SUZUKI, T. \& VOLLE, R.L.(1979). Nicotinic, muscarinic and adrenergic receptors in a parasympathetic ganglion. $J$. Pharmac. exp. Ther., 211, 252-256.

WALTERS, E.H., O'BYRNE, P.M., FABBRI, L.M., GRAF, P.D., HOLTZMAN, M.J. \& NADEL, J.A. (1984). Control of neurotransmission by prostaglandins in canine trachealis smooth muscle. J. appl. Physiol., 57, 129-134.

WETZEL, G.T. \& BROWN, J.H. (1985). Presynaptic modulation of acetylcholine release from cardiac parasympathetic neurones. Am. J. Physiol., 248, H33-H39.

(Received October 25, 1985. Accepted December 7, 1985.) 